\title{
Neuropathy Mimicking Radiculopathy After Extracorporeal Shock Wave Lithotripsy Treatment: A Case Report
}

\author{
Ekstrakorporeal Şok Dalga Litotripsi Tedavisi Sonras1 Radikülopatiyi \\ Taklit Eden Nöropati: Olgu Sunumu
}

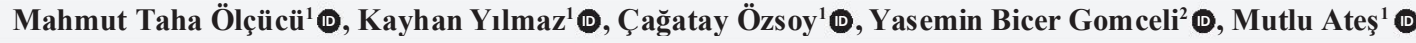 \\ ${ }^{1}$ University of Health Sciences, Antalya Training and Research Hospital, Department of Urology. Antalya, Turkey \\ ${ }^{2}$ University of Health Sciences, Antalya Training and Research Hospital, Department of Neurology. Antalya, Turkey
}

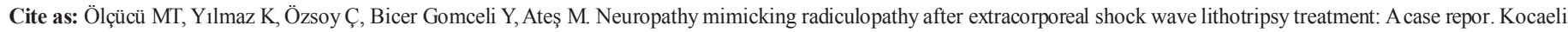
Med J 2021;10(2):102-105.

\begin{abstract}
We presented a 57-year-old female patient with neuropathy mimicking radiculopathy who underwent extracorporeal shock wave lithotripsy (ESWL) treatment for renal stone. After the second session of ESWL, the patient reported severe pain on the left side of the waist and sole of the left foot, tingling and burning of the sole of the left foot. She had no complaints before ESWL. After neurological examination, the patient was diagnosed as neuropathy due to the possible effects of ESWL on the spinal cord roots. Pregabalin $75 \mathrm{mg}$ twice a day was started and her symptoms were gradually recovered during the six months. This case demonstrates that neuronal structures in the regions adjacent to the targeted ESWL region can be affected by shock waves.
\end{abstract}

Keywords: extracorporeal shock wave lithotripsy, neuropathy, pregabalin, radiculopathy, renal stone

Öz

Böbrek taşı için ekstrakorporeal şok dalga litotripsi (ESWL) tedavisi uygulanan radikülopatiyi taklit eden nöropatili 57 yaşında bir kadın hasta sunduk. İkinci seans ESWL sonrası hasta, belin sol tarafında ve sol ayağın tabanında şiddetli ağrı, sol ayak tabanında karıncalanma ve yanma olduğunu belirtti. ESWL'den önce hiç şikayeti yoktu. Nörolojik muayeneden sonra, hastaya ESWL'nin omurilik sinir kökleri üzerindeki olası etkileri nedeniyle nöropati teşhisi konuldu. Pregabalin 75 mg p.o günde iki kez başlandı. Altıncı ayın sonunda hastanın sempmtomlarının şiddeti kademeli olarak azaldı. Bu olgu, hedeflenen ESWL bölgesine komşu bölgelerdeki nöronal yapıların şok dalgalarından etkilenebileceğini göstermektedir.
Geliş tarihi / Received: 08.06.2020

Kabul tarihi / Accepted: 02.08.2021

Sorumlu Yazar/Corresponding Author: Mahmut Taha Ölçücü

University of Health Sciences, Antalya Training and Research Hospital, Department of Urology. Antalya, Turkey matah_ol@hotmail.com ORCID: 0000-0002-4721-2807

K. Yılmaz 0000-0003-3592-4572

C. Özsoy 0000-0002-2124-865X

Y. Bicer Gomceli 0000-0001-5043-0891

M. Ateş 0000-0003-3951-4271

Anahtar Kelimeler: böbrek taşı, nöropati, pregabalin, radikulopati, şok dalga litotripsi 


\section{INTRODUCTION}

Urinary stone disease is common all over the world and has a lifetime prevalence of 5-10\% (1).Extracorporeal shock wave lithotripsy (ESWL) is the first choice for pelvis, middle pole and upper pole kidney stones up to $2 \mathrm{~cm}$, lower pole kidney stones up to $1.5 \mathrm{~cm}$ and upper ureter stones up to $1 \mathrm{~cm}(2,3,4)$. The contraindications of ESWL are pregnancy, bleeding diathesis or anticoagulant use, uncontrollable urinary infection, severe skeletal anomalies, severe obesity that prevents the stone to be targeted, arterial aneurysm around the stone and anatomic obstruction in the distal of the stone (3).

The kidneys are anatomically adjacent to the lumbar and thoracic vertebrae $\left(\mathrm{T}_{12}-\mathrm{L}_{3}\right)$. ESWL effects in the structures adjacent to the kidney, so it can cause complications in the adjacent tissues. Complications include renal hematoma, hemorrhage, edema, hematuria, perforations of the colon and duodenum, hematomas of the liver and spleen, pancreatitis, cardiac arrhythmias (5). The optimal shockwave frequency is $1.0-1.5 \mathrm{~Hz}(60-90 \mathrm{pulse} / \mathrm{min})$ and a total of 2000 pulses for urinary stone disease (3). The fact that ESWL has various side effects in neighboring organs shows that ESWL has effects not only in the areas it focuses on but also in the surrounding area.

Neuropathic pain is caused by the damage and/or disease of the somatosensory system. Traumatic nerve,spinal cord or brain injury, diabetes mellitus, herpes or human immunodeficiency virus and multiple skleroz can cause neuropathic pain (6). We reported a case of neuropathy which were caused by traumatic nerve (spinal cord root) injury after ESWL treatment for kidney stone.

\section{Case Report}

A 57-year-old female patient (height: $164 \mathrm{~cm}$, weight: 63 kg, BMI: 23.5) underwent endoscopic ureteral stone treatment and ureteral double $\mathrm{J}$ stent replacement due to left proximal ureteral stone in another hospital, and then she was applied to our urology clinic for the push-back of the stone into the left kidney. Computed tomography and a direct urinary system graphy (DUSG) were performed (Figure 1A and 1B). ESWL was planned for the radiopaque $7 \mathrm{~mm}$ and lower pole stone (734 H.U ) seen in both imaging studies. The skin-to-stone distance was $92 \mathrm{~mm}$. There was no contraindication for ESWL. ESWL was performed with the help of EMD Medical Technologies, Spectrum C-Arm, Germany-Turkey branded device. In the first session, ESWL was started with a frequency of 60 pulses $/ \mathrm{min}$ with $18 \mathrm{kV}$ energy and increased gradually up to $22 \mathrm{kV}$. A total of 2000 pulses were made. The patient had no complaints after the first session. Control imaging showed which was hardly visible minimal fragmentation in the DUSG (Figure 2.). We dediced to give a second chance of ESWL and susgested it to the patient. We informed patient if second session of ESWL failed, we could perform retrograde intrarenal surgery (RIRS). The patient has accepted our suggestion.

Eighteen days later, the second session performed. It was

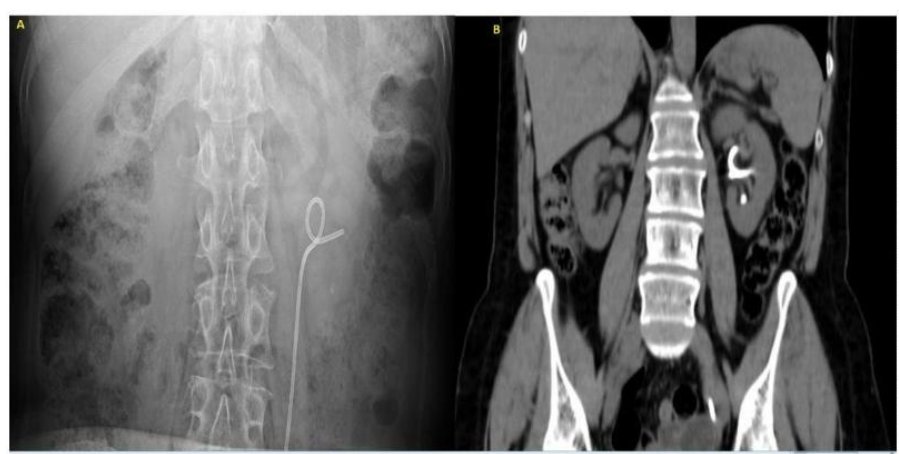

Figure 1. Imaging of left kidney lower pole stone. A. Direct urinary system graphy demonstrates the stone is radioopaque. B. Computed tomography of the stone. The targeted area of ESWL is adjacent to the lumbar vertebrae.

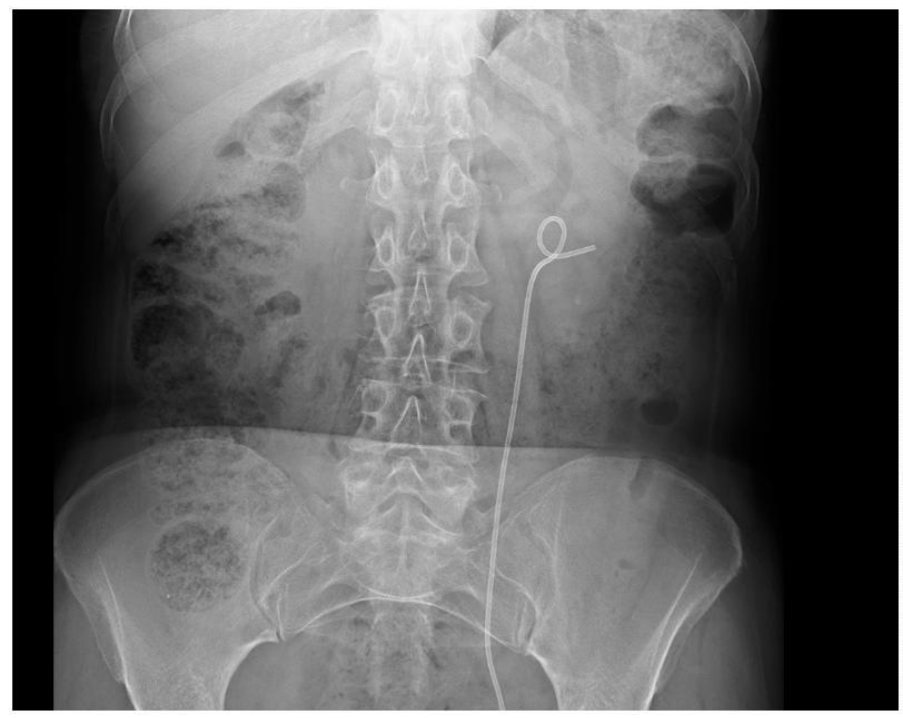

Figure 2. Control direct urinary system graphy of the patient.

started with a frequency of 60 pulses/min with $18 \mathrm{kV}$ energy and increased to $20 \mathrm{kV}$. The procedure was terminated due to severe pain at $20 \mathrm{kV}$. A total of 1500 pulses were made in this session. After the second session, the patient reported severe pain on the left side of the waist and sole of the left foot, tingling and burning of the sole of the left foot. She had no complaints before ESWL. Her complaints did not regress with muscle relaxant and analgesic therapy. She was consulted to neurology and physical therapy and rehabilitation. In the neurological examination, there was hypoesthesia at the $\mathrm{L}_{4}$ and $\mathrm{L}_{5}$ dermatome, the left plantar reflex was weak. Findings were thought of as lumbar radiculopathy. Electro myelography was reported as normal. Diffuse bulging findings were observed in the thoracic $\mathrm{T}_{9-10}$ and $\mathrm{L}_{2}-\mathrm{S}_{1}$ vertebrae in the thoracolumbar MRI (Figure 3). There were no compression findings in the spinal cord and roots.

The patient was diagnosed as neuropathy due to the possible effects of ESWL on the spinal cord roots. Pregabalin $75 \mathrm{mg}$ p.o twice a day was started and she was followed up with visual analog scoring (VAS) before and after treatment. Pre-treatment VAS was 8. Post-treatment VAS was 5, 3 and 1 for the first, third and sixth months, respectively. Tingling and burning of the soles of the left foot were relieved and plantar reflex returned to normal after treatment. In this period patient refused to undergo RIRS. 


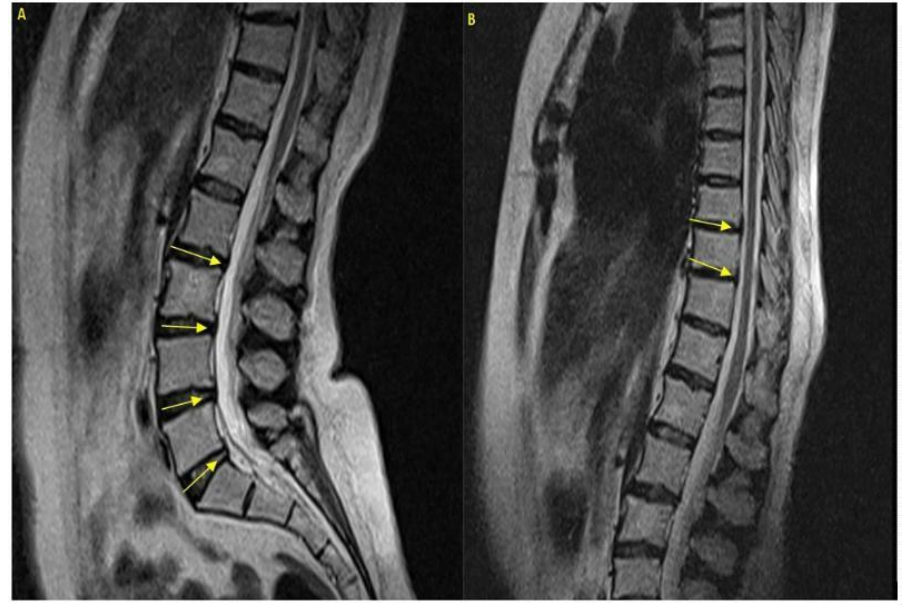

Figure 3. Magnetic resonance imaging of thoracolumbar area

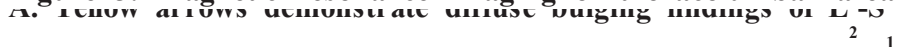
vertebrae B. Yellow arrows demonstrate diffuse bulging findings of $T_{9-10}$ vertebrae. No compression of the spinal cord or nerve root is seen in both imaging.

\section{DISCUSSION}

The studies which demonstrate the relationship between the ESWL and its effects on neural tissues are limited. Only a few studies are showing the effects of ESWL on neural tissues.

Karatas et al. investigated the histopathological effects of ESWL in medulla spinalis $\left(\mathrm{T}_{12}-\mathrm{L}_{1}\right.$ vertebrae) of rats (7). They were divided rats into 3 groups, each consisting of 5 rats. Group 1 (study) received low-dose ESWL (2000 impulses at $15 \mathrm{kV}$ ) and group 2 (study) received high-dose ESWL (2000 impulses at $18 \mathrm{kV}$ ). Group 3 (control) did not receive ESWL treatment. In the first week after ESWL, neural tissues were examined and reported that Group 2's myelin sheaths were damaged and the number of lysosomes increased compared to the other groups. They suggested the damage of the myelin sheath may impair the function of neural tissues and that the increase in the number of lysosomes may be associated with the destruction of the damaged areas in the tissue. However, they stated that the study was carried out in the 1st week after ESWL and further studies were needed for long term results. Also, in some studies of experimental spinal cord injury on rats, a low-dose shock wave has been reported to have positive effects on spinal cord healing $(8,9,10)$.

In a similar case report, Taşdemir et al. reported meralgia parasthetica (MP) in a 35-year-old patient after ESWL treatment (3000 shock waves) for left kidney stone (11). The complaints of patient were burning, pain and numbness in the anterolateral part of the left thigh. The diagnosis of MP has conducted by clinical findings and the cortical somatosensory evoked potential results in their case report. The complaints of patients were completely resolved after 1.5 months without treatment.

Newman et al. reported that dogs have weakened hind legs after ESWL applied to their ureter (12). However, they indicated that this weakness relieved after 48 hours. They suggested that ESWL may affect the lumbar plexus due to its proximity to the ureter. In the same study, they investigated the effects of ESWL on the spinal cord. They reported that there was no clinical effect of ESWL applied to the $\mathrm{L}_{3}-\mathrm{L} 4$ and $\mathrm{L}_{4}-\mathrm{L}_{5}$ range of dogs. Lorenzo et al. reported progressive flaccid paraplegia and acute urinary retention in a patient with posttraumatic thoracic syringomyelia who was treated with ESWL for ureteral stones (13). They suggested that the fluid in the syrinx cavity transmitted ESWL waves caused serious and irreversible damage to the spinal cord. Similarly, Tosi et al. reported acute urinary retention after ESWL in a patient with post-traumatic syringomyelia (14). They have also reported the patient's syringomyelia cavity grows on MRI after ESWL.

Pregabalin is a frequently used agent in neuropathic pain treatment. Pregabalin $75 \mathrm{mg}$ p.o twice a day can be a good option in the treatment of ESWL related neuropathic pain. However, pregabalin can cause serious side effects like blurred vision, hives, rash, and itching (15). Patients should be attended about the side effects before starting pregabalin treatment.

\section{CONCLUSION}

When the studies in the literature and our study are examined, it can be concluded that the shock wave affecting the neural tissue may have beneficial or harmful effects depending on the intensity and location. To our knowledge, this is the first case report for neuropathy after ESWL treatment for kidney stones which mimicking lumbar radiculopathy. We think that the neuronal structures in the areas adjacent to the targeted ESWL region can be affected by shock waves.

Ethics Statement: Our patient has given her consent to publish photos and details of her case.

Disclosure Statement: The authors declare that there are no conflicts of interest.

Funding Source: None.

\section{REFERENCES}

1. Olcucu MT, Teke K, Yalcin S, Olcucuoglu E, Caner V, Turk NS, Tuncay OL. Characterizing the Association Between Toll-like Receptor Subtypes and Nephrolithiasis With Renal Inflammation in an Animal Model. Urology 2018;111:238. e231-238. e235. https://doi.org/10.1016/j.urology.2017.09.026

2. Iqbal N, Malik Y, Nadeem U, Khalid M, Pirzada A, Majeed M, Malik HA, Akhter S. Comparison of ureteroscopic pneumatic lithotripsy and extracorporeal shock wave lithotripsy for the management of proximal ureteral stones: A single center experience. Turk J Urol 2018;44:221-227. https://doi.org/10.5152/tud.2018.41848

3. Turk C, Petrik A, Sarica K, Seitz C, Skolarikos A, Straub M, Knoll T. EAU Guidelines on Interventional Treatment for Urolithiasis. Eur Urol 2016;69:475-482.

https://doi.org/10.1016/j.eururo.2015.07.041 
4. Yildirim K, Olcucu MT, Colak ME. Trends in the treatment of urinary stone disease in Turkey. PeerJ 2018;6:e5390. https://doi.org/10.7717/peerj.5390

5. Skolarikos A, Alivizatos G, de la Rosette J. Extracorporeal shock wave lithotripsy 25 years later: complications and their prevention. Eur Urol 2006;50:981-990; discussion 990. https://doi.org/10.1016/j.eururo.2006.01.045

6. Treede RD, Jensen TS, Campbell JN, Cruccu G, Dostrovsky JO, Griffin JW, Hansson P, Hughes R, Nurmikko T, Serra J. Neuropathic pain: redefinition and a grading system for clinical and research purposes. Neurology 2008;70:1630-1635.

https://doi.org/10.1212/01.wnl.0000282763.29778.59

7. Karatas A, Dosoglu M, Zeyrek T, Kayikci A, Erol A, Can B. The effect of extracorporeal shock wave lithotripsy on the rat spinal cord. Spinal Cord 2008;46:627-632.

https://doi.org/10.1038/sc.2008.31

8. Yamaya S, Ozawa H, Kanno H, Kishimoto KN, Sekiguchi A, Tateda S, Yahata K, Ito K, Shimokawa H, Itoi E. Lowenergy extracorporeal shock wave therapy promotes vascular endothelial growth factor expression and improves locomotor recovery after spinal cord injury. J Neurosurg 2014;121:15141525. https://doi.org/10.3171/2014.8.JNS132562

9. Lee J-Y, Ha K-Y, Kim J-W, Seo J-Y, Kim Y-H. Does extracorporeal shock wave introduce alteration of microenvironment in cell therapy for chronic spinal cord injury? Spine 2014;39:E1553-E1559.

https://doi.org/10.1097/BRS.0000000000000626
10. Shin DC, Ha KY, Kim YH, Kim JW, Cho YK, Kim SI. Induction of Endogenous Neural Stem Cells By Extracorporeal Shock Waves After Spinal Cord Injury. Spine (Phila Pa 1976) 2018;43:E200-E207. https://doi.org/10.1097/BRS.0000000000002302

11. Tasdemir S, Ulas UH, Yucel M, Cetiz A. Meralgia paresthetica after the fragmentation of renal stone using extracorporeal shock wave lithotripsy: a case report. Acta neurologica Belgica 2016;116:423-424. https://doi.org/10.1007/s13760-015-0574-1

12. Newman RC, Hackett RL, Brock KA, Sosnowski J, Blackmore J, Ballinger WE, Feldman J, Finlayson B. Effect of ESWL on canine spinal cord. Urology 1987;29:116. https://doi.org/10.1016/0090-4295(87)90619-4

13. Di Lorenzo N, Maleci A, Williams BM. Severe exacerbation of post traumatic syringomyelia after lithotripsy. Case report. Paraplegia 1994;32:694-696. https://doi.org/10.1038/sc.1994.112

14. Tosi L, Terrini G. Lithotripsy in SCI patients. Spinal Cord 1995;33:364. https://doi.org/10.1038/sc.1995.82

15. Kaul I, Amin A, Rosenberg M, Rosenberg L, Meyer WJ, 3rd. Use of gabapentin and pregabalin for pruritus and neuropathic pain associated with major burn injury: A retrospective chart review. Burns : journal of the International Society for Burn Injuries 2018;44:414-422.

https://doi.org/10.1016/j.burns.2017.07.018 